\title{
The Law on Education of 2012 and Development of Educational Law in Russia
}

\section{目 Alexander Kozyrin}

Professor, Department of Financial, Tax and Customs Law, Law Faculty, National Research University Higher School of Economics, Doctor of Juridical Sciences. Address: 20 Myasnitskaya Str., Moscow 101000, Russia. E-mail: kozyrine@hse.ru

\section{凡目 Tatyana Troshkina}

Associate Professor, Department of Financial, Tax and Customs Law, Law Faculty, National Research University Higher School of Economics, Candidate of Juridical Sciences. Address: 20 Myasnitskaya Str., Moscow 101000, Russia. E-mail: ttroshkina@hse.ru

\section{聂国 Abstract}

In September 2013 Russia enacted a new law on education which introduced significant changes into the system of sources for Russian educational law. This article analyses the provisions of the education law that pertain to sources of educational law in the Russian Federation, the relationship between different levels of normative and legal regulation, including: international, national (federal laws and by-laws, legal regulation of relations in education at the regional and municipal levels in the Russian Federation), and the place of local normative acts within the mechanism for legal regulation of relations in education.

\section{O-1国 Keywords}

education, educational law, sources of legal regulation, legislation on education, constitutional fundamentals of educational legislation, international treaties.

Citation: Kozyrin A.N., Troshkina T.A. (2017) The Law on Education of 2012 and Development of Educational Law in Russia. Pravo. Zhurnal Vysshey shkoly ekonomiki, no 1, pp. 80-91 (in English)

DOI: 10.17323/2072-8166.2017.1.80.91

\section{Introduction}

In the Russian Federation the state of education directly impacts both public social policy and the national economic development strategy. In modern society, virtually all aspects of public life and social development, including the economy, public security, science and technology, culture, and the environment, depend on the level and quality of education.

It would seem imperative that such a significant segment of social life should have an adequate legal base. However, for years there has been a mismatch between the socio-political significance of education and its special role in the process of economic modernization in Russia, on the one hand, and the state of the normative-legal base regulating relations in education, on the other. 
The Law of the Russian Federation "On Education" ${ }^{1}$ adopted in 1992 needed considerable reworking by the late 1990s. An ever-increasing number of amendments had made Russia's educational legislation self-contradictory. Even so, perhaps the single greatest reason compelling the government to develop a new basic law on education was that the previous law had been adapted to regulate the Soviet model of education. A series of educational reforms in the late 1990s and the early 2000s brought about a radical change in the focus of normative-legal regulation, and it was necessary to pass a new basic law to make education legislation relevant to the new educational environment in Russia.

Initially, the authors of the new law went the way of codification and began to elaborate the Education Code of the Russian Federation. The Draft Code had been developed at the initiative of the Government of the Russian Federation and then submitted for public discussion. However, it was later decided not to enact the Code. Instead, the draft Federal Law "On Education in the Russian Federation" was developed to provide both general principles for regulating educational relations and norms regulating the individual levels of general and vocational education.

The new law on education has attracted much more attention from both the public and political parties than any other draft law. The number of amendments proposed during the course of public discussion was estimated in the thousands.

The new law on education was finally adopted ${ }^{2}$ at the end of 2012. The Federal Law of December 29, 2012 "On Education in the Russian Federation" (hereinafter, the Law on Education of 2012), coming into effect on September 1, 2013, became the foundation for designing the education legislation that needed updating to accommodate the social and economic environment of the 21st century, as well as the obligations assumed by Russia as it integrated with the European educational system, particularly by joining the Bologna Process.

\section{The Law on Education of 2012 and Updating Education Legislation}

The fundamental law serving as the basis for the design of legislation on education is the Law on Education of 2012. According to its Preamble, the Law:

- Establishes the legal, organizational and economic basis of education in the Russian Federation;

- Establishes the basic principles of Russian Federation state policy for education;

- Sets general rules governing the educational system and educational activity;

- Defines the legal status of the parties in educational relations.

However, the Law on Education of 2012 is not the sole legal source regulating relations in education at the federal level.

In addition to that law, the sources of the Russian educational law include core federal laws adopted to regulate relations in education (for example, the Federal Law on Moscow State University and Saint-Petersburg State University ${ }^{3}$ ), as well as a whole range of "non-core" laws.

Such non-core laws are adopted to regulate a variety of relations and contain separate provisions affecting education and educational activity. These laws may be grouped as follows:

\footnotetext{
${ }^{1}$ Law of the Russian Federation of July 10, 1992. No. 3266-1. Rossiyskaya Gazeta. No. 172. July 31, 1992.

2 Federal Law of December 29, 2012. No. 273-FZ // Collection of Legislation of the Russian Federation. 2012. No. 53. Art. 7598.

3 Federal Law of November 10, 2009 No. 259-FZ "On Moscow State Lomonosov University and Saint Petersburg State University” // Collection of Legislation... 2009. No. 46. Art. 5418.
} 
- Federal laws regulating fundamental organizational matters in education: "On Languages of the Peoples of the Russian Federation", "On Freedom of Conscience and Religious Associations", "On National Cultural Autonomy" and other laws;

- Federal laws with provisions regulating specific types of education: military education (“On Military Duty and Military Service”), sports training ("On Physical Culture and Sports in the Russian Federation"), professional education of persons sentenced to imprisonment (the Criminal Executive Code of the Russian Federation) and other federal acts;

- Federal laws which set the incentives for parties in educational relations: "On Additional Guarantees of Social Support to Orphaned Children and Children Left without Parental Care", "On the Social Protection of Disabled Persons in the Russian Federation", "On Alternative Civil Service" and others;

- Federal laws regulating labor relations and setting the procedure for social maintenance of parties in educational relations: "On the Procedure for Establishing the Amounts of Grants and Social Payments in the Russian Federation", the Labor Code of the Russian Federation and others;

- Federal laws regulating relations in the economy and in the finance of education: the Civil Code of the Russian Federation; the Tax Code of the Russian Federation, the Budget Code of the Russian Federation, the Federal Law "On Autonomous Institutions" and others;

- Federal laws establishing criminal and civil offenses in education: the Criminal Code of the Russian Federation, the Code on Civil Offenses.

If this is sufficient to show that some norms regulating relations arising in education are not derived from legislation on education as such (for example the norms of tax, criminal and civil law), then the conclusion that most of these other norms of educational law are derived from the non-core laws reflects the absence of a systematic approach to the legal regulation of education. In practice, this situation can lead to a variety of legal collisions and definitely reduces the effectiveness of legal regulation.

Let us delve into the concept of "education legislation" as it is defined in the Law on Education of 2012.

Since Soviet times a dual approach to the concept of legislation has been followed in legal studies. Jurists made a distinction between legislation in a broad and narrow sense. In the narrow (proper) sense legislation was taken to be a set of laws derived from the normative legal acts adopted by legislative bodies and having supreme legal force. Legislation in the broad sense meant the external expression of objective law, the aggregate of generally binding legal acts. This concept of legislation covered various legal acts issued by authorized state bodies and establishing the rule of law. They included both legislative acts and regulations.

The predominance of a broad approach to the definition of legislation stems from a refusal to accept the principle of separation of powers and the concentration of legislative and executive powers in the councils, the governmental authorities of that period ${ }^{4}$.

In the reaction against Soviet ideological dogmas lawmaking practices during the 1990s were gradually tending to adopt the narrow (proper) sense of legislation. The departure from the broad approach to defining legislation was fixed in the Civil Code of the Russian Federation of November 30, 1994, in which civil law was defined as a set of laws comprising the Civil Code

${ }^{4}$ In addition to these, several other bodies were authorized to issue acts of a legislative character during the Soviet period. Prior to the adoption of the USSR Constitution in 1936, the legislative authorities included the Congress of Councils, the Central Executive Committee and the Council of People's Commissars, and commissariats were also entitled to issue legislative acts in the first years of Soviet government up to 1920. 
and other federal laws adopted in accordance with the code and regulating civil relations ${ }^{5}$. (The term "legislation" in the narrow (proper) sense of the word is used in most of the current codes (the Labor Code [Article 5], the Land Code [Article 2], the Forestry Code [Article 2] and others).

In present-day lawmaking practice, however, the approach to defining legislation is extremely inconsistent. In some newly adopted codes and other federal laws there are examples indicating a return to the concept of legislation in the broad sense. Legislation is still being understood as a certain normative base that is not homogeneous in its legal nature ${ }^{6}$.

Such inconsistency in the approach to defining legislation indicates the absence of an established concept for lawmaking.

According to the Law "On Education" of 1992 (Article 3), the Constitution of the Russian Federation, the Law on Education itself, as well as "laws and other federal legislative acts of the Russian Federation adopted in accordance therewith, laws and other normative legal acts in the field of education of the constituent entities of the Russian Federation" constituted the education legislation of the Russian Federation. Introduction of "other normative legal acts" into the composition of education legislation meant actually resorting to the concept of legislation in the broad sense as a set of legislative acts and normative acts of a subordinate nature (such as decrees of the President, decisions of the government, orders from ministries and others).

The Law on Education of 2012 (Article 4) retains the concept of "education legislation" provided for in the Law of 1992: "Relations in the field of education shall be regulated by the Constitution of the Russian Federation, the present Federal law, and other federal laws, normative legal acts of the Russian Federation, and laws and other normative legal acts of the subjects [constituent entities of the Russian Federation] containing norms regulating relations in the field of education (hereinafter, education legislation)".

This state of affairs in Russian legislation can hardly be regarded as satisfactory because, for example, the legislation refers exclusively to legislative acts when regulating labor and family relations, while regulation of relations in the field of education is based on legislation including both legislative acts proper and numerous subordinate normative legal acts adopted in accordance with them.

Article 4 of the Law on Education of 2012 establishes the system of legal regulation of relations in education.

Despite the obvious importance of legislative acts in regulating educational relations, the system of sources for educational law is not limited to laws alone.

${ }^{5}$ It is noteworthy that the relevant article of the Civil Code of the Russian Federation (Article 3) is called the "Civil Legislation and Other Acts Containing Norms of Civil Law". Para 3, 4 and 7 of the article provide for the possibility of adopting normative acts regulating civil relations by the President of the Russian Federation, the Government of the RF and federal ministries. However, such normative acts are of a subordinate nature and are not to be included in the civil legislation.

${ }^{6}$ For example, Article 5 of the Housing Code of the Russian Federation states that the housing legislation consists of the Housing Code of the Russian Federation, other federal laws adopted in accordance with the code, and decrees of the President of the RF, decisions of Government of the RF, normative legal acts of federal executive bodies, and other normative legal acts issued by the constituent entities of the Russian Federation, and normative legal acts of local self-government bodies. According to Article 2 of the Federal Law of January 10, 2002 No.7-FZ "On Environmental Protection", the legislation on environmental protection includes the Federal Law "On Environment Protection" along with other federal and regional normative legal acts adopted in accordance with the law.

Both these examples exhibit the broad approach to defining legislation, under which legislation is understood as a collection of normative legal acts. These examples represent legislative acts adopted ten years after the adoption of the Civil Code of the Russian Federation in which its authors referred to "legislation" in the narrow (proper) sense. 
Along with legislative acts, it includes the Constitution of the Russian Federation, which contains fundamental principles of educational law and determines the right of everyone to education; international treaties of the Russian Federation establishing international legal commitments of the Russian Federation in the field of education; subordinate acts issuing by the head of state, the government and federal executive bodies; normative legal acts regulating educational relations at the regional level (the level of the subject [the constituent entity] of the Russian Federation) and at the municipal level, as well as local normative acts.

\section{The Constitutional Fundamentals of Educational Legislation}

The supreme position in the hierarchy of sources for Russian educational law belongs to the Constitution of the Russian Federation, which celebrated its 20th anniversary in 2013.

The supreme legal force of the Constitution in legal regulation of education is determined first by the constitutional provision (Article 15) according to which "the Constitution of the Russian Federation shall have the supreme juridical force, direct action, and shall be used on the whole territory of the Russian Federation; laws and other legal acts adopted in the Russian Federation shall not contradict the Constitution of the Russian Federation". Second, the force of the Constitution is conditioned by the goals and objectives of education legislation, which are established in the Law on Education of 2012.

The aim of education legislation is the establishment of state guarantees and mechanisms for exercising human rights and freedoms in education. Among its main objectives is ensuring and defending the constitutional right to education of citizens of the Russian Federation.

The constitutional basis of educational law is determined in Article 43, which provides for the right of every Russian citizen to education, and Article 72 referring general education issues to the joint jurisdiction of the Russian Federation and the constituent entities of the Russian Federation, as well as in Article 114 establishing that the Government of the Russian Federation should ensure implementation of uniform state policy for education ${ }^{7}$.

Constitutional provisions of educational law may be further elaborated through decisions issued by the Constitutional Court of the Russian Federation.

\section{International Treaties and Educational Legislation}

The development of academic mobility, international exchanges in education, science and culture, and modern processes in the globalization of education require substantial international legal regulation of educational relations.

To date, a significant set of international legal acts pertaining to education has already been formulated, and these can provisionally be called international educational law.

The norms governing educational relations may be contained in:

- International legal acts of a universal character adopted under the auspices of the UN, UNESCO, the International Labor Organization and others;

7 The supreme position of the Constitution of the Russian Federation within the system of educational law and the provision requiring conformity of all other sources of educational law to the Constitution, are obvious. At the same time, this special place of the Constitution cannot be considered as grounds for attributing acts of education legislation to it (such a conclusion might be drawn based on the meaning of the norm provided in the Para 1 of Article 4 of the Law on Education of 2012). The wording of the Para 1, Article 4 in its current form is due to the legal and technical insufficiency of the new law on education. 
- Regional international legal acts issued within the Council of Europe, the CIS, or the EurAsEC;

- Various international bilateral cooperation agreements in education, science and culture.

Provisions of international educational law can be included in international treaties regulating educational relations only and may also be incorporated in international treaties in which educational matters are addressed directly or indirectly, along with other matters (the International Covenant on Economic, Social and Cultural Rights, the Covenant on the Rights of the Child, etc.).

To define the relationship between Russian education legislation and the provisions of international treaties of the Russian Federation, the legislator in Para 6, Article 4 of the Law on Education of 2012 adduces the constitutional principle of the priority international treaties formulated in Article 15 of the Constitution of the Russian Federation: "If an international treaty of the Russian Federation sets other rules than those envisaged by Federal law, the rules of the international agreement shall be applied".

\section{Subordinate Normative Legal Acts Adopted at the Federal Level}

Even if educational relations are governed in detail at the legislative level, there is always a need for legal regulation implemented through by-law regulations. Issuing subordinate legal acts is more efficient because it allows rapid responses to new developments in education. In certain cases the rules of federal laws refer directly to the normative legal acts to be adopted by the Government or by federal executive authorities.

As already noted, subordinate normative acts are to be included in education legislation in accordance with the definition of education legislation contained in the Article 4 of the Law on Education of 2012, This brings about an extension of the legislation and requires establishing clear standards for its formulation and ensuring its conformity with the basic provisions of the Law on Education of 2012.

The legal guarantees of integrity and consistency in education legislation are set forth in the norms of the Law on Education of 2012, which:

- Establish the basic principles of state policy and legal regulation of relations in education (Article 3);

- Set the goals and objectives of the legal regulation of relations in education (Para 2, 3 of Article 4);

- Fix the principle, according to which the norms of subordinate legal acts must conform to the Law on Education of 2012 and may not restrict the rights or limit the guarantees established by the Law (Para 4, Article 4);

- State the rule for resolving legal conflicts that may arise in education legislation: in the event of a discrepancy between the by-law norms regulating relations in education and the norms of the Law on Education of 2012, the norms of the Law on Education are to be applied (Para 5, Article 4);

- Fix powers of federal executive bodies in the field of education (Article 6).

The system of sources of educational law at the federal level includes decrees of the President of the Russian Federation, decisions of the Government of the Russian Federation, as well as orders issued by the federal executive bodies.

These acts are to be adopted to regulate exclusively educational relations or are to contain separate provisions concerning relations in education if they are issued to regulate other relations. 
The President of the Russian Federation exercises legislative powers in education pursuant to his constitutional authority to determine the main directions of state policy in science and education.

The Decrees of the President concern the most important endeavors of state educational policy, public administration in education, and guarantees of the constitutional right of every citizen to education (for example, Decrees of the President of the Russian Federation of May 7, 2012 No. 599 "On Measures for Implementation of the State Policy in the Field of Science and Education"; of March 4, 2010 No. 271 "Issues of the Ministry of Education and Science of the Russian Federation"; and of May 7, 2008 No. 716 "On Federal Universities”).

In order to facilitate implementation of the President's authority in education and science, the Department on Science and Education Policy was established within the structure of the Presidential Administration. According to the Regulation on the Department approved by the Presidential Decree of June 25, 2012 No. 882, the main functions of the Department include support in developing draft decrees, orders and instructions of the President of the Russian Federation on science and education.

In order to develop science and education in the Russian Federation and to improve public administration in this field, the Council under the President of the Russian Federation on Science and Education was established as an advisory body under the head of state to facilitate interaction among federal public authorities, public authorities of the constituent entities of the Russian Federation, local self-government bodies, public associations, and scientific and educational institutions. Its mission is to ensure cooperation among them on issues related to scientific and educational development, as well as to prepare proposals for the President of the Russian Federation on urgent public policy issues pertaining to the progress of science and education. The Council's activity is regulated by the Decree of the President of the Russian Federation of July 28, 2012, No. 1059 "On the Council on Science and Education under the President of the Russian Federation". One of the main tasks of the Council is to develop proposals for the President of the Russian Federation that set the priorities and mechanisms for scientific and educational development in the Russian Federation, along with measures providing for implementation of public policy in science and education.

The Government of the Russian Federation is vested with significant law-making authorities in the field of education. The Law on Education of 2012 contains regulations binding the Government of the Russian Federation to issue by-law normative acts. For example, by Article 11 the Government must approve the procedure for elaboration, endorsement and amendment of the Federal State Educational Standards (Decision of the Government of the Russian Federation of August 5, 2013 No. 661). In compliance with Article 46, the Government of the Russian Federation is entitled to approve the list of teaching and managerial employees of educational organizations (Decision of the Government of the Russian Federation of August 8, 2013 No. 678); Article 54 specifies the right to approve the rules for rendering paid educational services (Decision of the Government of the Russian Federation of August 15, 2013 No. 706), etc.

The Department of Science, High Technology and Education formed within the structure of the Government apparatus, supports the Government's activities on matters within its scope and interacts with the appropriate federal executive bodies and other public authorities and organizations (Para 12 of the Regulation on the Apparatus of the Government of the Russian Federation approved by the Decision of the Government of June 1, 2004 No. 260). The tasks of the Department include developing draft acts to be issued as decisions by the Government (Para 13 of the Regulations).

Perhaps the largest group of subordinate normative legal acts adopted at the federal level for regulating educational relations is constituted by orders of the federal executive bodies. 
The federal executive body which develops state policy and carries out normative legal regulation in education is the Ministry of Education and Science of the Russian Federation (Decision of the RF Government of June 3, 2013 No. 466). The Regulation on the Ministry of Education and Science contains a list of more than 70 (!) activities in education to be governed by the normative legal acts of the Ministry, and this list remains open. It includes:

- Procedures for populating the list of professions, specialties and types of training and indicating the qualifications for each respective profession, specialty and type of training;

- Organization and implementation rules for educational activities by educational programs (at different levels and/or orientations) or by types of education;

- Procedures for applying e-learning and other distance learning technologies in the educational programs of educational organizations;

- Procedures for developing the federal specifications applicable to textbooks recommended for use in state accredited educational programs offering primary general, basic general, and secondary general education;

- The conditions and procedures for transferring students from paid education to free education;

- The grounds and procedures for allowing academic leave to students;

- The list of indicators, criteria and required frequency for evaluating the effectiveness of development programs implemented by the national research universities;

- And many others.

The Ministry of Education and Science holds a central place in the system of bodies charged with public administration of education, but it is not the sole federal executive authority vested with powers to implement normative legal regulation in education (Para 4, Article 89 of the Law on Education of 2012). Along with the Ministry of Education of Russia, subordinate normative legal acts may be also issued by federal state bodies responsible for educational organizations. As examples there are the orders of the Ministry of Health of Russia of September 3, 2013 No. 62 "On Approval of the Procedure for Organization and Conducting of Internship in the Vocational Education Programs of Medical Education and Pharmaceutical Education"; the decrees of the Minister of Defense of the Russian Federation of April 24, 2010 No. 100 "On Approval of the Instruction on the Conditions and Procedure for Admission to Study in the Military Higher Vocational Education Organizations of the Ministry of Defense of the Russian Federation"; the orders of the Ministry of Justice of Russia of November 21, 2005 No. 223 "On Organizing of the Acquisition of Basic General and Secondary (Complete) General Education by Prisoners in the Evening (Shift) General Education School of Correctional Colony of the Penal Executive System" and other acts.

\section{Normative Legal Acts Adopted at the Level of a Constituent Entity of the Russian Federation}

According to the education legislation and in other areas for which the Constitution of the Russian Federation assigns legislative regulation to the joint jurisdiction of the Russian Federation and its constituent entities, the concept of "legislation" includes regional laws (laws of the constituent entities of the Russian Federation) along with the federal ones.

The Law on Education of 2012 defines the powers of state bodies of the constituent entities of the Russian Federation in education (Article 7), as well as the federal powers in education that may be delegated to the state authorities of the constituent entities of the Russian Federation (Article 6). 
In addition, the Law (Para 4 and 5, Article 4) establishes the principle of conformity of regional legislation to the Law on Education of 2012 as follows:

- Provisions of the laws and other normative legal acts of the constituent entities of the Russian Federation regulating relations in education are to conform to the Law on Education of 2012 and may not restrict the rights or limit the guarantees established by the Law;

- If provisions of regional acts of education legislation do not conform to the provisions of the Law on Education of 2012, the provisions of the federal law are to be applied.

The normative legal acts regulating general aspects of educational activity in a specific region are distinguished from regional education laws and other normative legal acts (the Law of Moscow of June 20, 2001 "On Educational Development in Moscow", the Law of Republic of Dagestan of November 3, 2006 "On Education" and other acts) as are the normative legal acts on matters within the competence of the constituent entities of the Russian Federation (the Law of Belgorod Region of July 3, 2006 "On Establishing Regional Component of the Federal State Educational Standards of General Education in Belgorod Region"; the Law of Stavropol Territory of February 10, 2009 "On Cadet Education and Cadet Educational Organizations"; Decree of the President of Republic of Bashkortostan of December 31, 2009, "On Approval of the Concept of National Educational Development in the Republic of Bashkortostan"; Decision of the Head of Administration of Krasnodar Territory of December 31, 2004 "On Approval of Regulations on Procedures for Admission to State Educational Organizations for Primary Vocational Education in Krasnodar Territory" and other acts).

A special place among the sources of educational law is held by normative legal acts establishing specific guarantees for the parties in educational relations (the Law of Moscow of April 28, 2010 "On the Education of Persons with Special Needs in Moscow"; the Law of Khabarovsk Territory of February 14, 2005 "On Measures of Social Support to Employees of Educational Organizations and Additional Guarantees Ensuring the Right to Education for Certain Categories of Students"), as well as by acts regulating economic and financial relations in education (the Law of the Republic of Buryatia of July 11, 2011 "On Established Standards of Financial Provision for General Education in Republic of Buryatia"; the Law of the Amur Region of August 29, 2011 "On Financial Provision for State Guarantees Ensuring the Rights of Citizens to Public Schools and Free Access to Pre-Schools, General and Supplemental Education in General Educational Organizations").

Regional education legislation is now being revisited because many of the existing normative legal acts had been approved long before the adoption of the Law on Education of 2012. The constituent entities of the Russian Federation have begun the process of bringing the regional education legislation into compliance with the provisions of the Federal Law of 2012. A new generation of laws on education have already been enacted in some regions: the Law of Saint Petersburg of July 17, 2013 "On Education in Saint Petersburg"; the Law of Omsk Region of July 18, 2013 "On Regulation of Relations in Education in the Omsk Region"; the Law of the Tula Region of September 30, 2013 "On Education" the Law of the Republic of Altay of November 15, 2013 "On Education in Republic of Altay" and other laws.

\section{Municipal Normative Legal Acts in Education}

Municipal entities are also vested with certain powers in education. In conformity with the Federal Law of October 6, 2003 No. 131-FZ “On General Principles of Organization of Local Self-Government in the Russian Federation”, the issues of local importance include:

- Organization of public and free access to primary general, basic general, and secondary general education within general education programs; 
- Providing additional education for children and public free pre-school education on the territory of municipal entity;

- Organization of recreation for children during school vacation, etc.

The powers of local self-government bodies in municipalities and urban districts in education are established in Article 9 of the Law on Education of 2012.

Local self-government bodies and their officials are to adopt municipal legal acts on matters of local importance binding within the territory of the municipal entity.

Thus, a provision of the educational law may be incorporated into a normative legal act issued at the municipal level ${ }^{8}$.

The municipal acts regulating educational relations comprise the largest group of sources for educational law. They are issued by local self-government bodies on educational matters within the competence of the municipal authorities (Decision of the Council of Deputies of the Kolomna Urban District of the Moscow Region of March 29, 2013 "On Approval of the Regulations on the Procedure for Charging Parents [Legal Representatives] for Child Care in the Educational Organizations of the Kolomna Urban District Providing Pre-school Education in the Basic General Curricula"; the Decision of the Petrozavodsk City Council of September 28, 2010 "On Approval of Regulations on the Organization of Additional Education for Children in the Municipal Educational Organizations of the Petrozavodsk Urban District"; Resolution of the Head of the Executive Committee of the Nabarezhnye Chelny City Municipality of April 24, 2007 "On Approval of Regulations on the Organization of Vocational Recreation for Children in Naberezhnye Chelny City"; Resolution of the Head of the Administration of Makhachala of June 3, 2010 "On the Approval of Regulations on the Remuneration of Labor to the Employees of the Municipal Educational Organizations in Makhachkala”, etc.).

Analogous to the normative legal acts issued by the constituent entities of the Russian Federation, norms issued through municipal legal acts regulating educational relations are also required to conform to the provisions of the federal law as specified by the Law on Education of 2012 (Para 4,5, Article 4).

This principle contributes to the unity and consistency of the legislation on education and allows for municipal sources of educational law adopted prior to 2012.

\section{Local Normative Acts}

What is novel in the Law on Education of 2012 is the inclusion of a separate article devoted to local normative acts ${ }^{9}$ within the body of the law. Local acts (orders, regulations, rules, rules of procedure, directives and so on) have special significance for the legal regulation of educational relations because they are issued by educational organizations on the main issues of the organization and performance of educational activities. They set the rules for admission to education, training schedules, the manner of monitoring progress, and interim assessment of students. The acts also establish the procedures and grounds for the transfer, expulsion and

8 There is an inconsistency in relation to municipal acts in Article 4 of the Law on Education of 2012. These acts are not mentioned in the Para 1, Article 4, which lists the forms of legal regulation of educational relations. However, in Para 4 and 5 of the same article, the legislator establishes the requirement that norms contained in municipal acts conform to the provisions of the Federal Law; and in the event that a conflict between norms should arise, priority is given to the provisions of the Law on Education of 2012.

9 Local acts regulate educational relations concerning specific educational organizations and as such should be mentioned in Article 4 of the Law on Education of 2012 that lists all forms of legal regulation of relations in education. 
reenrollment of students and so on. Matters governed by the local acts are "closer" to the parties in educational legal relations. The local acts often provide the first experience of using the sources of educational law for students and parents of the minor students.

Requirements for local acts are set forth in the Law on Education of 2012. According to Article 30 of the Law, local normative acts shall be adopted:

- First, in compliance with the legislation of the Russian Federation; they should not contain provisions that worsen the position of the students or the employees of educational organizations in comparison with the position envisaged by the provisions of education and labor legislation;

- Second, within the competence of the educational organization from which they originate;

- Third, in accordance with the Charter of the respective educational organization.

Local regulations that do not meet these requirements may not be applied and are to be annulled by the issuing educational organization. The Law on Education of 2012 stipulates the negative consequences for local acts adopted in contravention of the requirements established by the Law. These provisions are aimed at ensuring the unity and consistency of the entire system of legal regulation of educational relations.

The value of local normative acts and their special place in the system of sources for educational law are justified by the fact that the procedures for their development and adoption in cases where they concern the rights of students and employees of educational organizations take into account the opinion of the students' councils, parent councils, and employees' representatives.

Such procedures permit "fine tuning" of local normative acts and recognize the interests of all parties in educational relations.

\section{Conclusion}

The year 2013 will figure in the history of modern Russian law as the year when the new federal law on education came into effect. Nearly everyone agrees on the importance of this legislation for all aspects of Russian socio-economic life. The urgent need for legislative reforms in education was obvious inasmuch as the previous Law on Education of 1992 had long been outdated.

Vehement debates held the stage during discussion of the draft law, and they are continuing because of different views on the content and ways to implement educational reform in the Russian Federation. We did not touch upon the issues related to reforming the educational system in this article or upon the expediency and effectiveness of changes in particular norms: the form of the educational law was the focus of this study rather than its content.

Has the adoption of the new law on education facilitated the formulation of an effective system for legal regulation of education? The answer to this question will be apparent later in the practices of law enforcement. However, we can already say that the task of systemizing legislation that regulates relations in education still remains on the agenda. The fact that regulation of the most important aspects of educational policy is carried out based on dozens (!) of various federal laws would lead to the conclusion that efforts at systemizing have been incomplete, while it also complicates the process of making all the numerous regional and municipal acts regulating relations in education fall into compliance with the federal legislation. Of course, this sort of disarray in the legislative basis applicable to education impedes its use by the ultimate subjects of educational law, who without any exaggeration comprise most of the Russian population. 
Therefore, we can conclude that, when the new law on education came into effect in 2013, a lengthy stage in reworking education legislation was completed. However, the task of systemizing it and optimizing its legal forms is still to come.

\section{I国 References}

Bratanovsky S.N., Kocherga S.A. (2016) Administrativnye prava grazhdan v sphere obrazovaniya [Administrative Rights of Citizens in the Sphere of Education]. Administrativnoie pravo, no 1, pp. 28-33. Durand-Prinborgne C. (1998) Le droit de l' éducation. Enseignements scholaires. Traité théorique et practique. Paris: Hachette, $480 \mathrm{p}$.

Fedorova M.Yu. (2004) Obrazovatelnoye pravo [Educational Law]. Moscow: Vlados, 320 p. (in Russian) Kozyrin A.N. (2008) Sovremennye problemy sistematizatsii obrazovatelnogo zakonodatelstva [Modern Issues of Educational Legislation Systematization]. Ezhegodnik rossijskogo obrazovatel'nogo zakonodatel'stva [Yearbook of Russian Educational Legislation]. Moscow: FSOZ, vol. 3, no 2, pp. 5-30. Kozyrin A.N., Troshkina T.N., Yalbulganov A.A. (2011) Obrazovatelnoye pravo kak uchebnaya disciplina [Educational Law as an Academic Subject]. Reformy i pravo, no 4, pp. 50-54.

Kozyrin A.N. (ed.) (2015) Obrazovaniye: Zakon i grazhdanin [Education: Law and Citizen]. Bibliotechka Rossijskoj Gazety, issue 17, 176 p.

Kozyrin A.N., Troshkina T.N. (2015) Osnovnye printsipy gosuderastvennoi politiki i pravovogo regulirovaniya otnosheniy $v$ sphere obrazovaniya: commentarii $k$ statie 3 federalnogo zakona Ob obrazovanii v Rossiyskoy Federatsii [Basic Principles of State Policy and Legal Regulation of Relations in the Field of Education: Commentary to Article 3 of the Federal Law "On Education in the Russian Federation"]. Reformy i pravo, no 3, pp. 18-32.

Kozyrin A.N., Korf D.V., Yalbulganov A.A. (2010) Upravlenie obrazovaniem: sravnitelnyi analiz rossiyskogo i zarubezhnogo zakonodatelstva [Educational Management: Comparative Analysis of Russian and Foreign Legislation]. Reformy i pravo, no 3, pp. 43-62.

Kuzibetskiy A.N. (ed.) (2015). Obrazovatelnoye pravo [Educational Law]. Moscow: Academia Press, 256 p. (in Russian)

Russo C. (ed.) (2013) Handbook of Comparative Higher Educational Law. N.Y.: Rowman and Littlefield, $394 \mathrm{p}$.

Spasskaya V.V. (2005) Obrazovatelnye otnoshenia: voprosy teorii [Educational Legal Relations: Theoretical Issues]. Moscow: Locus-Press, 168 p. (in Russian)

Syrikh V.M. (2002) Vvedenie $v$ teoriu obrazovatelnogo prava [Introduction to Educational Law Theory]. Moscow: FSOZ, 400 p. (in Russian)

Troshkina T.N. (2011) Ponyatie i structura obrazovatelnogo pravootnoshenia [Concept and Structure of Educational Legal Relations]. Reformy i pravo, no 3, pp. 56-61.

Tsomartova F.V., Kachmazova L.G. (2014) Poluchenie obrazovania vne obrazovatelnuch organizatsiy: pravovye perspectivy [Education outside Educational Organizations: Legal Prospects]. Zhurnal rossiyskogo prava, no 2, pp. 27-36.

Vidal Prado C. (2001) La libertad de càtedra: uno studio comparado. Madrid: Centro de Estudios Politicos y Constitucionales, $309 \mathrm{p}$. 